\title{
Sistem Ekonomi (Islam) dan Pelarangan Riba dalam Perspektif Historis
}

\author{
${ }^{1 *}$ RisandaAlirastra Budiantoro, ${ }^{2}$ Riesanda Najmi Sasmita, ${ }^{3}$ Tika Widiastuti \\ ${ }^{1,2,3}$ Sekolah Pascasarjana,Universitas Airlangga, Indonesia \\ *Email korenpondensi: risanda.abe@gmail.com
}

Recieved 29-11-2017| Revised 16-03-2018 | Accepted 20-03-2018

\begin{abstract}
Allah has given the guidance in the form of Islam for Muslim to take and lead all the aspects of life including the economic activity. The Islamic economic system is believed to be the answer of the economic problems that exist at this time. The goal is to achieve falah in kaffah by not doing some economic activities that are in violation as prescribed by Islam. For example is riba. Discourse on riba can be said "classical" both in the development of Islamic thought and in Islamic civilization because riba often occurs in all aspects of public life, especially economic transactions (in Islam called muamalah). Riba is an additional retrieval, either in a sale and purchase transaction or lending in a false or contrary to the principle of muamalah in Islam. Prohibition of riba is obtained from various sources by the Qur'an and Hadith Rasulullah SAW, so the scholars firmly and clearly defined the prohibition of riba because there are exploitative elements that can harm the others. So, this study is aimed to identif yIslamic economic system and the prohibition of riba in historical perspective. From the results of this study is expected to be a good reference for the reader to understand the Islamic economic system and riba in the future.
\end{abstract}

Keywords: Economics System, Islamic Economic, Historical Perspective, Riba

Saran sitasi: Budiantoro, R., Sasmita, R., \& Widiastuti, T. (2018). Sistem Ekonomi (Islam) dan Pelarangan Riba dalam Perspektif Historis. Jurnal Ilmiah Ekonomi Islam, 4(01), 1-13. doi: http://dx.doi.org/10.29040/jiei.v4i1.138

DOI: http://dx.doi.org/10.29040/jiei.v4i1.138

\section{Pendahuluan}

Allah telah memberikan tuntunan berupa agama Islam untuk dijadikan pedoman dalam menempuh dan menjalani segala aspek kehidupan termasuk dalam perekonomian. Islam menganjurkan bahwa setiap perbuatan ekonomi maupun perbuatan lainnya harus dilandasi oleh iman, takwa (aqidah) dan aturan yang telah digariskan (syariah) serta perilaku (akhlak) yang dicontohkan oleh Rasulullah saw. Allah dengan tegas menyatakan bahwa hanya Islamlah agama yang diridhai dan diterima oleh Allah:

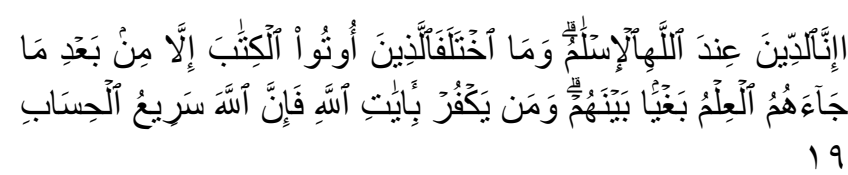

"Sesungguhnya agama (yang diridhai) oleh Allah hanyalah Islam. Tiada berselisih orangorang yang telah diberi Al Kitab kecuali sesudah datang pengetahuan kepada mereka, karena kedengkian (yang ada) diantara mereka. Barangsiapa yang kafir terhadap ayat-ayat Allah maka sesungguhnya Allah sangat cepat hisabnya" (QS. Ali Imran(3): 19). 
Menurut Tafsir Ibnu Katsir, bahwasanya tidak ada agama di sisi-Nya yang diterima dari seseorang selain islam. Yaitu mengikuti para Rasul dalam setiap apa yang mereka bawa pada setiap saat hingga berakhir pada Muhammad. Melalui ayat ini, Allah memberitahukan batasan, bahwa agama yang diterima di sisi-Nya hanyalah Islam. Selanjutnya Allah memberitahukan bahwa orang-orang yang telah diberi Al-Kitab di masamasa yang lalu berbeda pendapat setelah adanya hujjah bagi mereka dengan diutusnya Rasul kepada mereka serta diturunkannya kita-kitab kepada para Rasul tersebut. Sebagian mereka merasa dengki atas sebagian lainnya sehingga mereka berselisih dalam hal kebenaran lantaran mereka membawa kebencian kepada sebagian yang lain. Kepada penentangan terhadap sebagian yang lain dalam seluruh ucapan dan perbuatannya, meskipun benar. Allah akan memberikan balasan atas perbuatan tersebut dan menghisabnya atas kedustaan yang telah diperbuatnya serta menyiksanya atas penolakannya terhadap Kitab-Nya.

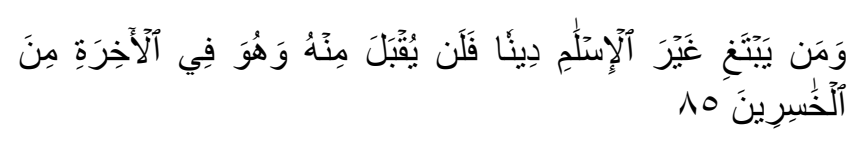

"Barangsiapa yang mencari agama selain agama Islam, maka sekali-kali tidaklah akan diterima (agama itu) daripadanya, dan dia di akhirat termasuk orang-orang yang rugi" (QS. Ali Imran(3): 85).

Menurut tafsir Ibnu Katsir, ayat ini menjelaskan tentang barangsiapa menempuh jalan selain yang telah disyari'atkan Allah, maka Dia tidak akan menerimanya. Barangsiapa mengerjakan suatu amalan yang tidak ada dasar perintahnya dari kami, maka amalannya itu ditolak.

Dalam konteks ekonomi konvensional, ekonomi diartikan sebagai hal-hal yang berkaitan dengan produksi, distribusi, konsumsi dari kekayaan atau harta benda; atau hal-hal yang berkaitan dengan pemenuhan kebutuhan material atau kebendaan manusia (Iljas, 2007). Secara tata bahasa, ekonomi berasal dari dua suku kata yaitu oikos yang berarti rumah tangga dan nomos yang berarti aturan, sehingga ilmu ekonomi merupakan imu yang mengatur rumah tangga (Samuelson \& Nordhaus, 2001). Dalam pelaksanaannya ekonomi memusatkan perhatiannya untuk memenuhi kebutuhan manusia berdasarkan kepada ketiga proses kegiatan ekonomi (produksi konsumsi dan pertukaran) dengan melibatkan pihak-pihak yang terkait kegiatan tersebut (produsen, konsumen, pemerintah) (Boediono, 2011). Perekonomian bekerja dan dijalankan dalam sebuah sistem yang terstruktur, sistematis dan cakupannya luas. Secara umum, sistem ekonomi menggabungkan beberapa aspek kegiatan ekonomi dalam suatu negara tertentu. Sehingga, sistem ekonomi diartikan sebagai cara pandang atau mekanisme pengoragnisasian kegiatan ekonomi atas empat dasar dasar, yaitu (1) apakah kepemilikian atas harta kekayaan didominir oleh individu (swasta) dan publik (pemerintah); (2) apakah pengambilan keputusan dilakukan oleh mekanisme pasar atau dengan campur tangan pemerintah; (3) tingkat sentralisasi dan desentralisasi dalam pengambilan keputusan eknomi; dan (4) kemana produksi dan distribusi diarahkan (Iljas, 2007).

Namun, jika dipandang berdasarkan ajaran Islam, aktivitas perekonomian yang dilakukan manusia harus memiliki beberapa kaedah dan etika atau moralitassesuai syariat Islam. Menurut Arif (2015), ekonomi Islam didefinisikan sebagai perilaku individu Muslim dalam setiap aktivitas ekonomi syariahnya harus sesuai dengan tuntutan syariat Islam, dalam rangka mewujudkan dan menjaga maqashid syariah (agama, jiwa, akal, nasab, dan harta). Allah telah menurunkan rizki ke dunia ini untuk dimanfaatkan oleh manusia dengan cara yang telah dihalalkan oleh Allah dan bersih dari segala aktifitas riba. Riba adalah pengambilan tambahan, baik dalam transaksi jual beli maupun pinjam-meminjam secara bathil atau bertentangan dengan prinsip muamalah dalam Islam (Antonio, 2001). Pelarangan riba ini didapat dari berbagai sumber Al-Qur'an dan Hadith Rasulullah saw, sehingga para ulama menetapkan dengan tegas dan jelas pelarangan 
riba karena riba mengandung unsur eksploitasi yang akan merugikan orang lain.

Diskursus mengenai riba dapat dikatakan "klasik" baik dalam perkembangan pemikiran Islam maupun dalam peradaban Islam karena riba sering terjadi di dalam segala aspek kehidupan masyarakat terutama transaksi-transaksi ekonomi (dalam Islam disebut muamalah) yang sering dilakukan oleh masyarakat dalam keseharian. Terdapat perbedaan pandangan diantara para cendikiawan muslim sejak masa klasik, pertengahan hingga modern. Perbedaan ini timbul terutama pada masa modern saat ini, karena masih belum adanya keseragaman pemikiran dan pandangan dari cendikiawan muslim mengenai hukum riba. Ketika pemikiran ini lebih dikembangkan ke belakang, sebenarnya permasalahan ini terjadi karena adanya perbedaan dalam hal penafsiran terhadap ayat-ayat tentang riba, walaupun perbedaan dalam penafsiran bersifat wajar pembahasan.

Beberapa penelitian sebelumnya terkait riba, seperti yang dilakukan Rahmawaty (2013), melakukan kajian mengenai riba dalam persepektif keuangan Islam di Indonesia. Dalam pembahasannya riba menjadi dikursus dalam ilmu ekonomi islam yang berdebatannya hampir tidak menemukan titik temu. Pedebatan pemikiran menunjukkan bahwa persoalan riba sangat terkait dengan masalah uang sehingga tidak lepas dari peran lembaga keuangan. Hasilnya sebagai solusi alternatif Islam menawarkan sistem profit loss sharing yang diharapkan mampu untuk menggantikan sistem bunga dalam perekonomian Islam. Hal ini diperkuat oleh penelitian yang dilakukan oleh Chamid (2013), melihat krisis ekonomi yang terjadi di dunia karena negara yang terlibat tersebut menerapkan sistem ekonomi kapitalisme. Sistem ekonomi tersebut dibangun atas sektor moneter atau keuangan (non riil). Sehingga kapitalisme tidak dapat dilepaskan dari unsur bunga (riba). Hal ini tidak sesuai dengan pandangan Islam yang mengharamkan riba atau suku bunga. Sebagai hasil penelitiannya seharusnya otoritas ekonomi global mulai menyadari dan mengikuti untuk membangun ekonomi keuangan berbasis sektor rill seperti yang dijalankan pada sistem ekonomi Islam pada saat ini (Hidayanto, 2008), melakukan penelitian mengenai praktik riba yang dapat menimbulkan kesenjangan sosial. Salah satu dari ajaran Islam yang penting adalah mengekkan keadilan dan menghapuskan eksploitasi dalam transaksi ekonomi, sehingga melarang seluruh aktifitas yang dapat meningkatkan kekayaan secara tidak adil, termasuk riba. Hasil dari penelitiannya menjelaskan bahwa tidak ada riba yang halal, semua jenis riba haram, seperti yang ditegaskan dalam Al-Qur'an yang menghalalkan jual beli dan mengharamkan riba

Berkaitan dengan wacana diatas, Jurnal ini akan memberikan gambaran mengenai sistem ekonomi Islam dan pelarangan riba dalam tinjauan historis. Masalah yang dibahas dalam penelitian ini dibatasi pada sistem ekonomi Islam dan praktek riba yang dilarang oleh Islam dalam tinjauan historis. Penelitian secara khusus akan melihat karakteristik, tujuan dan prinsip dasar sistem ekonomi Islam, pengertian riba, sejarah pelarangan riba sebelum Islam, tahapan pelarangan riba dalam Al-Quran, macam-macam riba dan menawarkan solusi profit-loss sharing atas pelarangan riba.Harapannya dari hasil studi ini dapat dijadikan acuan baik pembaca untuk lebih dapat memahami akad sistem ekonomi Islam dan praktek riba kedepannya.

Bertitik tolak dari latar belakang masalah sebagaimana dikemukakan di atas, maka dapat dirumuskan beberapa masalah kajian sebagai berikut: 1) Apa tujuan, prinsip dan berkembangnya sistem ekonomi Islam?; 2) Bagaimana konsep riba dalam ekonomi Islam?; 3) Bagaimana latar belakang historis munculnya riba?; 4) Bagaimana landasan hukum atas pelarangan riba?; dan 5) Bagaimana solusi Islam terhadap pengganti alternatif sistem bunga?

\section{Metode Penelitian}

Penelitian ini merupakan kajian literatur yang bersumber pada berbagai kajian studi yang telah dilakukan sebelumnya, serta didukung dengan hasil kajian yang dipublikasikan oleh 
berbagai lembaga berupa jurnal dan kajian ilmiah lainnya.

\section{Hasil dan Pembahasan}

\subsection{Ekonomi dan Sistem Ekonomi}

Dalam sejarah peradaban manusia, ada beberapa bentuk sistem ekonomi yang pernah ditemukan. Sistem yang paling primitif adalah depotisme, yaitu sistem ekonomi yang diatur oleh otoritas tunggal, baik seorang atau sekelompok orang yang menjadi pemimpin sistem ekonomi tersebut. Problematika dari depotisme yaitu tidak berkelanjutan dan tidak mampu untuk mengatasi problem yang semakin kompleks dihadapi oleh umat Islam (Arif, 2015).

Selanjutnya sistem ekonomi modern. Ketika membahas sistem ini terbagi menjadi dua sistem ekonomi besar yaitu sistem ekonomi kapitalisme pasar dan sosialisme terpemimpin. Pertama, sistem ekonomi kapitalisme, sistem yang didasarkan pada pertukaran sukarela (voluntary exchanges) dalam mekanisme pasar (campur tangan pemerintah minimum), kebebasan perseorangan diakui (liberalisme atau Laissez faire) dan menganut asumsi self-interest (individu dianggap mengetahui apa yang terbaik baginya). Sebaliknya sosialisme mencoba mengatasi permasalahan ekonomi melalui perencanaan dan komando, seperti yang diajarkan oleh Karl Marx, sistem ini muncul atas keprihatinan penderitaan masyarakat, segala bentuk kepimilikan dimiliki oleh negara (kepemilikan individu tidak diakui).

Gagalnya sistem ekonomi kapitalisme dan sosialisme menciptakan kesejahteraan masyarakat mendorong negara muslim untuk mencari sistem yang lebih baik yang mampu berperan dalam semua elemen untuk mencapai kebahagiaan umat. Lahirnya sistem ekonomi Islam didasarkan pada pemikiran bahwa sebagai agama yang lengkap dan sempurna, Islam tidak hanya memberikan penganutnya aturan-aturan soal ketuhanan dan iman, namun juga menjawab persoalan yang dihadapi manusia termasuk ekonomi.

\subsubsection{Tujuan Sistem Ekonomi Islam}

Ekonomi Islam dibangun atas dasar agama Islam, karenanya merupakan bagian yang tidak terpisahkan dalam berbagai aspek dari agama Islam. Islam merupakan way of life dimana Islam telah menyediakan perangkat aturan lengkap bagi kehidupan manusia termasuk dalam ekonomi. Islam bukan hanya berkaitan dengan spriritualitas atau ritualitas namun jauh lebih luas dari itu. Islam merupakan serangkaian keyakinan,

Tabel 1 Aspek Mikro dan Aspek Makro dalam Falah

\begin{tabular}{|c|c|c|}
\hline Unsur Falah & Aspek Mikro & Aspek Makro \\
\hline \multirow{4}{*}{$\begin{array}{l}\text { Kelangsungan } \\
\text { Hidup }\end{array}$} & $\begin{array}{l}\text { Kelangsungan hidup biologis: Kesehatan, } \\
\text { kebebasan keturunan, dan sebagainya }\end{array}$ & $\begin{array}{l}\text { Keseimbangan ekologi dan } \\
\text { lingkungan }\end{array}$ \\
\hline & $\begin{array}{l}\text { Kelangsungan hidup ekonomi: } \\
\text { kepemilikan faktor produksi }\end{array}$ & $\begin{array}{l}\text { - Pengelolaan sumber daya alam } \\
\text { - } \quad \begin{array}{l}\text { Penyediaan kesempatan beru- } \\
\text { saha untuk semua penduduk }\end{array}\end{array}$ \\
\hline & $\begin{array}{l}\text { Kelangsungan hidup politik: } \\
\text { Kebebasan dalam partisipasi politik }\end{array}$ & Jati diri dan kemandirian \\
\hline & $\begin{array}{l}\text { Kelangsungan hidup sosial: } \\
\text { Persaudaraan dan harmoni hubungan } \\
\text { sosial }\end{array}$ & $\begin{array}{l}\text { Kebersamaan sosial, ketiadaan } \\
\text { konflik antarkelompok }\end{array}$ \\
\hline \multirow{2}{*}{$\begin{array}{l}\text { Kebebasan } \\
\text { berkeinginan }\end{array}$} & Terbebas kemiskinan & $\begin{array}{l}\text { Penyediaan sumber daya untuk } \\
\text { seluruh penduduk }\end{array}$ \\
\hline & Kemandirian hidup & $\begin{array}{l}\text { Penyediaan sumber daya untuk } \\
\text { generasi yang akan dating }\end{array}$ \\
\hline \multirow{2}{*}{$\begin{array}{l}\text { Kekuatan dan } \\
\text { harga diri }\end{array}$} & Harga diri & $\begin{array}{l}\text { Kekuatan ekonomi dan kebebasan } \\
\text { dari hutang }\end{array}$ \\
\hline & $\begin{array}{l}\text { Kemerdekaan, perlindungan terhadap } \\
\text { hidup dan kehormatan }\end{array}$ & Kekuatan militer \\
\hline
\end{tabular}

Sumber: Khan(1994) 
ketentuan dan peraturan serta tuntutan moral bagi setiap aspek kehidupan manusia sehingga akan mencapai kebahagiaan baik di dunia maupun di akhirat.

Dalam ajaran Islam dikenal dengan istilah falah yang berasal dari bahasa arabaflaha-yuflihu artinya kesuksesan, kemuliaan, dan kemenangan. Untuk kehidupan di dunia, falah mencakup tiga pengertian yaitu kelangsungan hidup, kebebasan berkeinginan serta kekuatan dan kehormatan. Falah merupakan konsep yang multidimensi yang memiliki implikasinya pada perilaku individual (mikro) maupun perilaku kolektif (makro) seperti yang digambarkan pada Tabel 1. Sedangkan untuk kehidupan di akhirat, falah mencakup pengertian kelangsungan hidup yang abadi, kesejahteraan abadi dan kemuliaan abadi (bebas dari segala kebodohan) (Pusat Pengkajian dan Pengembangan Ekonomi Islam, 2-3).

Sejalan dengan pemikiran (Arif, 2015), tujuan yang ingin dicapai dalam suatu sistem ekonomi Islam berdasarkan konsep dasar Islam, yaitu tauhid dan berdasarkan pada Al-Qur'an dan Hadith Nabi saw adalah:

a. Memenuhi kebutuhan dasar manusia, meliputi pangan, sandang, papan, kesehatan, dan pendidikan untuk setiap lapisan masyarakat;

b. Memastikan kesetaraan kesempatan untuk semua orang;

c. Mencegah terjadinya pemusatan kekayaan dan meminimalkan ketimpangan dana distribusi pendapatan dan kekayaan di masyarakat;

d. Memastikan kepada setiap orang kebebasan untuk mematuhi nilai-nilai moral;

e. Memastikan stabilitas dan pertumbuhan ekonomi.

Hal tersebut juga diperkuat dengan pemikiran dari Iljas (2007), yang menyatakan tujuan sistem ekonomi Islam meliputi:

a. Mencapai sukses atau falah (kebahagiaan, kemenangan) manusia di dunia dan di akhirat.

b. Menjadikan distribusi sumber-sumber ekonomi, kekayaan dan pendapatan wajar dan merata. Dalam Islam, terdapat pelarangan bahwa harta tidak boleh hanya dikuasai oleh beberapa orang/kelompok saja. c. Memenuhi kebutuhan pokok, seperti makanan, pakaian, rumah kepada semua anggota masyarakat.

d. Membangun dan mengembangkan keadilan sosial bagi seluruh anggota masyarakat.

e. Membangun dan mengembangkan persaudaraan dan persatuan antara sesama muslim.

f. Pengembangan moral dan material dalam masyarakat Islam.

g. Mencegah penumpukan harta dan menjaga agar harta selalu berputar.

h. Penghapusan eksploitasi manusia atas manusia lainnya.

Prinsip-prinsip yang menjadi dasar dalam ekonomi Islam, yakni: (1) hanya Allah SWT yang menentukan benar dan salah atau halal dan haram. Manusia tidak mempunyai wewenang untuk menetapkan apa yang benar dan salah. Hal ini terdapat dalam QS. Al-Maidah (5):87-88; (2) prinsip kegunaan atau kemanfaatan. Allah SWT memberikan kebebasan kepada manusia untuk menikmati seluruh ciptaan Allah SWT dengan cara sederhana dan tidak berlebihan. Hal ini terdapat dalam QS. Al-Baqarah (2): 168, QS. An-Nahl (16): 114, dan QS. Al-A'raf (7): 31; (3) prinsip kesederhanaan. Manusia dianjurkan untuk hidup sederhana dalam mengumpulan harta benda dengan cara yang halal dan tidak tamak (gila harta). Hal ini dijelaskan dalam QS. Al-Baqarah (2): 143, dan QS. Al-Furqan (25): 67; (4) prinsip kebebasan ekonomi. Manusia diberikan kebebasan dalam bidang konsumsi, produksi, distribusi, dll dengan cara yang halal akan tetapi Islam tidak mengizinkan kebebasan yang tidak terbatas dalam ekonomi; (5) prinsip keadilan. Keadilan berlaku dalam segala aspek kehidupan manusia, termasuk ekonomi.

Terdapat asas yang mendasari perekonomian Islam dalam nilai-nilai yang Islam yang menjadi filosofi ekonomi Islam itu sendiri. Menurut (Arif, n.d.), asas tersebut adalah:

a. Asas suka sama suka,

b. Asas keadilan,

c. Asas saling menguntungkan, dan

d. Asas tolong menolong dan dilarang adanya pemerasan dan eksploitasi 


\subsubsection{Sistem Ekonomi Syariah Perspektif Historis}

Sistem ekonomi syariah dari perspektif historis dapat dilihat pada Gambar 1.

Perkembangan pemikiran ekonomi klasik dibagi menjadi tiga fase, yaitu (Mujahidin, 2013): fase pertama (113 H/738 M sampai $450 \mathrm{M} / 1058$ $\mathrm{H}$ ), diantara pemikir Muslim yang memberikan kontribusi pemikiran ekonomi Islam adalah Abu Yusuf yang menuangkan gagasan tentang ekonomi dalam kitab Al-Kharaj (Manual on Land Tax) pada masalah-masalah keuangan publik, pajak tanah, dan pendistribusian langsung tanggung jawab pemerintah dalam ekonomi terutama kebutuhan publik (jalan, irigasi). Selain itu Abu Ubaid Al-Qosim ibn Salam dengan karyanya 'Al-Amwal (The Wealth) yang berisis tentang sistem finansial dalam Islam. Fase kedua (450-850 H atau 1058-1466 M). Sejumlah ulama besar yang memberikan kontribusinya seperti:
Imam Al-Ghazali, Ibnu Taimiyah, dan Ibn Khaldun. Al-Ghazali merupakan ahli filsafat, teologi, fiqih, dan tasawuf. Kitab Ihya 'Ulum AdDin (The Revival of religious Science) yang berisi fungsi uang sebagai alat tukar dan larangan riba al-fadl (karena bertentangan dengan sifat dan fungsi uang). Teori-teori ekonomi yang berada di kitab tersebut masih relevan dengan kondisi perekonomian pada saat ini. Taqiuddin Ibnu Taimiyyah merupakan seorang ahli hadis, ilmu kalam, fiqih dan filsafat. Hasil pemikirannya dalam kitab Al-Hisbah fi Al-Islam dan Majmu' Al-fatawa tidak secara langsung berkaitan dengan masalah-masalah ekonomi namun tetap memperkaya khazanah intelektual muslim dalam studi ilmu ekonomi Islam. Ibn Khaldun merupakan seorang ahli sejarah dan filsafat terbesar yang pernah dihasilkan dunia Islam dan karyanya Muqadimmah tidak diragukan lagi. Pokok pembahasannya terkait masalah

Gambar 1 Sistem Ekonomi Islam: Perspektif Syariah

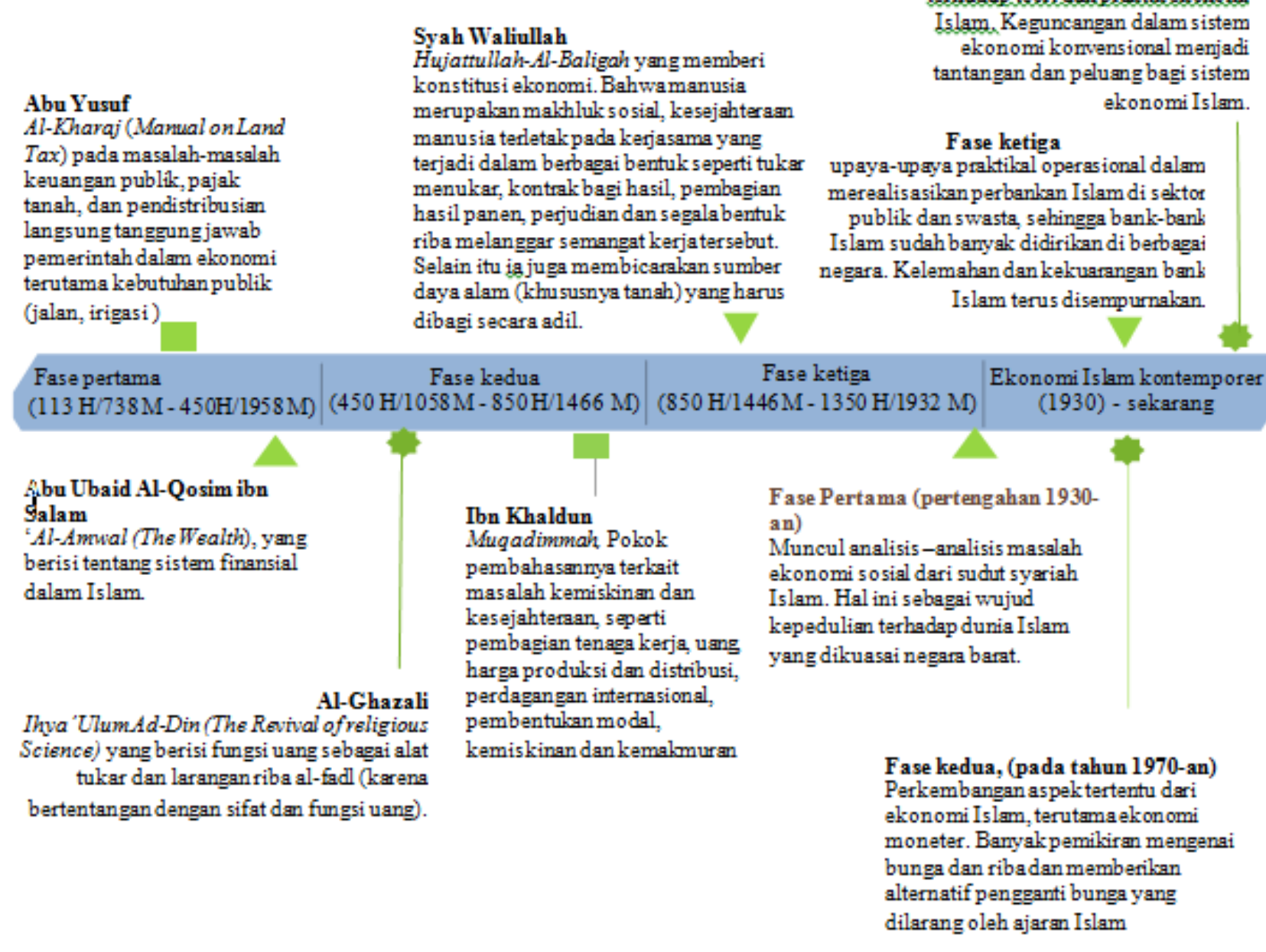


kemiskinan dan kesejahteraan, seperti pembagian tenaga kerja, uang, harga produksi dan distribusi, perdagangan internasional, pembentukan modal, kemiskinan dan kemakmuran. Fase ketiga (850$1350 \mathrm{H}$ atau 1446-1932 M) hanya ada satu tokoh dalam fase ini Syah Waliullah dengan karyanya Hujattullah-Al-Baligah yang memberi konstitusi ekonomi. Sejalan dengan pandangan Ibn Khaldun, ia berpendapat bahwa manusia merupakan makhluk sosial, kesejahteraan manusia terletak pada kerjasama yang terjadi dalam berbagai bentuk seperti tukar menukar, kontrak bagi hasil, pembagian hasil panen, perjudian dan segala bentuk riba melanggar semangat kerja tersebut. Selain itu, ia juga membicarakan sumber daya alam (khususnya tanah) yang harus dibagi secara adil.

Perkembangan ekonomi Islam kontemporer dari 1930 hingga sekarang dibagi menjadi empat fase, antara lain (Mujahidin, 2013): Fase Pertama, pertengahan 1930-an, muncul analisis-analisis masalah ekonomi sosial dari sudut syariah Islam. Hal ini sebagai wujud kepedulian terhadap dunia Islam yang dikuasai negara barat. Kebanyakan analisis ini berasal dari ulama yang tidak memiliki pendidikan formal ekonomi. Fase kedua, pada tahun 1970-an, perkembangan aspek tertentu dari ekonomi Islam, terutama ekonomi moneter. Banyak pemikiran mengenai bunga dan riba dan memberikan alternatif pengganti bunga yang dilarang oleh ajaran Islam. Fase ketiga, upaya-upaya praktikal operasional dalam merealisasikan perbankan Islam di sektor publik dan swasta, sehingga bank-bank Islam sudah banyak didirikan di berbagai negara. Kelemahan dan kekurangan bank Islam terus disempurnakan. Fase keempat, pembahasan lebih komprehensif terhadap teori dan praktik ekonomi Islam. Keguncangan dalam sistem ekonomi konvensional menjadi tantangan dan peluang bagi sistem ekonomi Islam.

\subsection{Konsep Riba}

Riba secara bahasa berarti tambahan. Sedangkan menurut istilah riba berarti pengambilan tambahan dari harta pokok secara batil. Secara umum, riba adalah pengambilan tamba- han, baik dalam transaksi jual beli maupun pinjam-meminjam secara batil atau bertentangan dengan prinsip muamalah dalam Islam (Antonio, 2001:37). Larangan ini terdapat dalam firman Allah SWT, yang berbunyi:

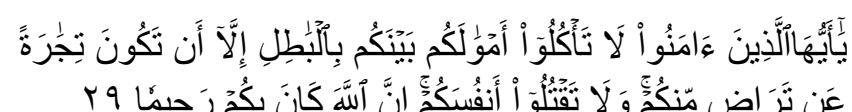

"Hai orang-orang yang beriman, janganlah kamu saling memakan harta sesamamu dengan jalan yang batilkecuali dengan jalan perniagaan yang berlaku dengan suka sama-suka di antara kamu. Dan janganlah kamu membunuh dirimu; sesungguhnya Allah adalah Maha Penyayang kepadamu” (QS. An-Nisaa': 29)

Dalam ayat diatas jelas bahwa Allah SWT melarang kita untuk mengambil tambahan (riba) pada segala bentuk kegiatan bermuamalah. (Arif, 2015) menyebutkan bahwa unsur penting yang membentuk riba adalah yang ditambahkan pada pokok pinjaman, besarnya tambahan menurut jangka waktu, dan jumlah pembayaran tambahan berdasarkan kesepatakan yang disepakati.

Riba dikelompokkan menjadi dua, yaitu riba utang-piutang dan riba jual beli. Riba utangpiutang dibagi lagi menjadi riba qardh dan riba jahiliyyah, sedangkan riba jual beli dibagi menjadi riba fadhl dan riba nasi'ah.

1. Riba Qardh (رباالقرض)

Suatu tambahan yang diambil dengan tingkat kelebihan tertentu yang disyaratkan kepada yang berhutang.

2. Riba Jahiliyyah (رباالجاهلية)

Suatu tambahan yang diberikan dari pokok pinjaman dikarenakan peminjam tidak bisa membayar hutang dengan tepat waktu.

3. Riba Fadhl (ربالفضل)

Pertukaran barang ribawi sejenis dengan takaran yang berbeda.

4. Riba Nasi'ah (ربالنسيئة)

Penangguhan penyerahan atau penerimaan jenis barang ribawi yang dipertukarkan dengan barang jenis ribawa lainnya. 


\subsection{Riba: Sebuah Tinjauan Historis}

Konsep riba sebenarnya sudah lama dikenal dan banyak mengalami perkembangan dalam pemaknaan. Riba bukan hanya diperbincangkan oleh umat Islam saja, tapi berbagai kalangan non-Islam pun memandang riba sebagai permasalahan yang serius. Jika melihat sejarahnya hingga dua ribu tahun yang lalu, kajian riba ini telah dibahas dalam Hindu, Budha (Rivai, Veitzhal, \& Idroes, 2007) Yahudi, Yunani, Romawi dan Kristen (Antonio, 2001)

Konsep riba di kalangan Yahudi, dikenal dengan istilah "Neshekh" yang artinya dilarang dan hina. Pelarangan ini banyak terdapat didalam kitab suci mereka (Old Testament-Perjanjian lama; maupun dalam Undang Undang Talmud), diantaranya adalah sebagai berikut (Antonio, 2001):

1. Kitab Exodus (Keluaran) pasal 22 ayat 25 menyatakan sebagai berikut:

"Jika engkau meminjamkan uang kepada salah seorang dari umat-Ku, orang yang miskin di antaramu, maka janganlah engkau berlaku sebagai penagih utang terhadap dia; janganlah engkau bebankan bunga uang terhadapnya".

2. Kitab Deuteronomy (Ulangan) pasal 23 ayat 19 menyebutkan sebagai berikut:

"Janganlah engkau membungakan kepada saudaramu, baik uang maupun bahan makanan atau apapun yang dapat dibungakan".

3. Kitab Levicitus (Imamat) pasal 25 ayat 36-37 menyatakan sebagai berikut:

"Janganlah engkau mengambil bunga uang atau riba darinya, melainkan engkau harus takut akan Allahmu, supaya saudaramu bisa hidup di antaramu. Janganlah engkau memberi uangmu kepadanya dengan meminta bunga, juga makananmu janganlah kau berikan dengan meminta riba".

Sedangkan pada masa Yunani dan Romawi Kuno, praktek riba merupakan tradisi yang lazim berlaku (Islahi, 1988). Pada masa Yunani sekitar abad VI SM hingga $1 \mathrm{M}$, terdapat beberapa jenis bunga yang bervariasi besarnya (Antonio,
2001:43). Pada masa Yunani terdapat klasifikasi bunga yang diperbolehkan, yaitu:

1) Pinjaman biasa : 6-18\%

2) Pinjaman properti: $6-12 \%$

3) Pinjaman antarkota: $7-12 \%$

4) Pinjaman perdagangan dan industri: 12$18 \%$

Sementara itu, pada masa Romawi, sekitar abad ke lima sebelum masehi hingga ke empat masehi, terdapat undang-undang yang membolehkan penduduknya mengambil bunga selama tingkat bunga tersebut sesuai dengan "tingkat maksimal yang dibenarkan hukum (maximum legal rate). Nilai suku bunga ini berubah-ubah sesuai dengan berubahnya waktu, namun pengambilannya tidak dibenarkan dengan cara bunga berbunga (double countable). Pada masa Romawi terdapat empat jenis tingkat bunga (Antonio, 2001).

1) Bunga maksimal yang dibenarkan: 8-12 persen;

2) Bunga pinjaman biasa di Roma: 4-12 persen;

3) Bunga di wilayah taklukan Roma: 6-100 persen;

4) Bunga khusus Byzantium: 4 - 12 persen

Meskipun demikian, praktik pengambilan bunga tersebut dicela oleh para ahli filsafat Yunani, diantaranya Plato (427-347 SM) dan Aristoteles (384-322 SM), begitu pula para ahli filsafat Romawi, seperti Cato (234-149 SM), Cicero (106-43 SM) dan Seneca (4 SM-65 M) mengutuk praktik bunga, yang digambarkannya sebagai tindakan tidak manusiawi (Islahi, 1988:124).

Konsep riba di kalangan Kristen mengalami perbedaan pandangan, yang secara umum dapat dikelompokkan menjadi tiga periode sebagai berikut: Pertama, pandangan para pendeta awal Kristen (abad I-XII) yang mengharamkan riba dengan merujuk pada Kitab Perjanjian Lama dan undang-undang dari gereja. Pada abad IV M, gereja Katolik Roma melarang praktik riba bagi para pendeta, yang kemudian diperluas bagi kalangan awam pada abad V M. Pada abad VIII M, di bawah kekuasaan Charlemagne, gereja Katolik Roma mendeklarasikan praktik riba 
sebagai tindakan kriminal (Iqbal \& Mirakhor, 2011). Kedua, pandangan para sarjana Kristen (abad XII-XVI) yang cenderung membolehkan bunga, dengan melakukan terobosan baru melalui upaya melegitimasi hukum, bunga dibedakan menjadi interest dan usury. Menurut mereka, interest adalah bunga yang diperbolehkan sedangkan usury adalah bunga yang berlebihan. Para sarjana Kristen yang memberikan kontribusi pemikiran bunga ini adalah Robert of Courcon (1152-1218), William of Auxxerre (1160-1220), St. Raymond of Pennaforte (1180-1278), St. Bonaventure (1221-1274) dan St. Thomas Aquinas (1225-1274) (Antonio, 2001). Ketiga, pandangan para reformis Kristen (abad XVI-1836) seperti Martin Luther (14831536), Zwingli (1454-1531), Bucer (1491-1551) dan John Calvin (1509-1564) yang menyebabkan agama Kristen menghalalkan bunga (interest). Pada periode ini, Raja Henry VIII memutuskan berpisah dengan Gereja Katolik Roma, dan pada tahun 1545 bunga (interest) resmi dibolehkan di Inggris asalkan tidak lebih dari 10 persen. Kebijakan ini kembali diperkuat oleh Ratu Elizabeth I pada tahun 157; Rivai, Veitzhal, \& Idroes, 2007).

Dengan latar belakang sejarah tersebut di atas, maka seluruh praktik operasionalisasi perbankan modern yang mulai tumbuh dan berkembang sejak abad XVI M ini menggunakan sistem bunga. Sistem bunga ini mulai tumbuh, mengakar, dan mendarah-daging dalam industri perbankan modern sehingga sulit untuk dipisahkan. Bahkan mereka beranggapan bahwa bunga adalah pusat berputarnya sistem perbankan. Jika tanpa bunga, maka sistem perbankan menjadi tak bernyawa dan akhirnya perekonomian akan lumpuh (Mannan, 1997).

Sementara itu, riba telah jelas dan tegas dilarang dalam Islam. Pelarangan riba dalam AlQur'an tidak diturunkan sekaligus melainkan secara bertahap, sejalan dengan kesiapan masyarakat pada masa itu, seperti pelarangan minuman keras.

\subsection{Dasar Hukum Pelarangan Riba}

\subsubsection{Larangan Riba dalam Alquran}

Riba dalam Islam hukumnya adalah haram. Menurut Antonio (2001) menyebutkan, larangan riba yang terdapat dalam Al-Qur'an melalui beberapa tahap, yaitu:

Tahap pertama, melalui QS. Ar-Rum ayat 39, yang berisi menolak anggapan bahwa pinjaman riba yang pada zahirnya untuk menolong mereka yang memerlukan sebagai sesuatu perbuatan yang mendekati atau taqarrub kepada Allah SWT.

Tahap kedua, melalui QS. An-Nisa' ayat 160-161, yang berisi pengharaman riba melalui kecaman Allah SWT terhadap praktik riba yang dilakukan oleh kaum Yahudi.

Tahap ketiga, melalui QS. Ali-Imran ayat 130, yang berisi bahwa riba yang diharamkan adalah yang bersifat berlipat ganda, dengan praktik pengambilan bunga (tambahan) dengan tingkat yang cukup tinggi. Kriteria berlipat ganda dalam ayat ini bukan merupakan syarat terjadinya riba, hal ini dikarenakan sifat karakteristik dari praktik pembungaan uang pada saat itu.

Tahap terakhir, melalui QS. Al-Baqarah ayat 278-279, yang berisi bahwa Allah SWT mengharamkan dengan jelas segala bentuk tambahan yang diambil dari pinjaman.

\subsubsection{Larangan Riba dalam Al-Hadith}

Seperti kita pahami, kegunaan dari hadith adalah menjelaskan secara lebih terperinci dan mendalam atas ketentuan-ketentuan yang telah digariskan oleh Al-Quran. Dalam amanat terakhirnya ketika khutbah haji wada' rasulullah menegaskan bahwa Islam melarang keras praktek riba. Rasulullah bersabda:

"Ingatlah bahwa semua riba yang diamalkan pada zaman jahiliyyah dihapuskan dari amalan kamu. Kamu berhak mengambil modal (uang pokok) yang kamu berikan, niscaya kamu tidak menzalami dan didzalami."(H.R Muslim)

Selain itu masih banyak haditt Rasulullah saw yang berkaitan dengan pelarangan riba diantaranya: 
1. “Jubir berkata bahwa Rasulullah SAW mengutuk orang yang merima riba,orang yang membayarnya, orang yang mencatatnya dan dua orang saksinya, kemudia beliau bersabda "Mereka itu semuanya sama" (H.R Muslim)

2. Dari Abu Hurairah r.a, Nabi bersabda, pada malam mi'raj saya telah bertemuy dengan orang yang perutnya besar seperti rumah, didalamnya dipenuhi ular-ular yang kelihatan dari luar, lalu saya bertanya kepada Jibril, siapakah mereka?, Jibril menjawab, mereka orang-orang yang memakan riba." (H.R Ibnu Majah)

\subsubsection{Larangan Riba dalam Ijma' Ulama}

Para ulama juga bersepakat (ijma') bahwa riba adalah haram, baik sedikit maupun banyak. Riba merupakan salah satu dari tujuh dosa besar yang harus dihindari. Dalam realitas kehidupan wujud riba sering dikaburkan atau disamarkan sehingga pemahaman ulama yang berbeda-beda dalam memahami maksud nash dalam memberikan hukum khususnya yang terjadi dalam perbankan, asuransi dan lembaga konvensional lainnya. Sehingga kaitannya dengan hal tersebut, fatwa ulama yang digunakan (Hidayanto, 2008):

1. Fatwa MUI

Pada tanggal 16 Desember 2013, Ulama komisi Fatwa MUI se-Indonesia menetapkan bahwa bank, asuransi, pegadaian, koperasi, dan lembaga keuangan lainnya maupun individu yang melakukan praktek bunga adalah haram. Ini berarti umat Islam tidak boleh melakukan transaksi pada lembaga keuangan tersebut. Pada awalnya fatwa pelarangan riba ini tidak berlaku untuk seluruh wilayah di Indonesia. Untuk wilayah tertentu yang belum terdapat kantor atau jaringan lembaga keuangan syariah diperbolehkan untuk melakukan kegiatan transaksi berdasarkan prinsip atau hajat (keperluan). Namun ketika sudah terdapat akses didalam lembaga keuangan syariah maka secara mutlak transaksi pada lembaga keuangan konvesional diharamkan.

2. Sidang Organisasi Konferensi Islam (OKI) Semua sidang OKI yang kedua yang dilaksanakan di Karachi, Pakistan pada
Desember 1970, telah menyetujui dua agenda yaitu:

a. Praktek bank dengan sistem bunga tidak sesuai dengan syariat islam;

b. Perlu segera didirikan bank alternatif yang menjalankan operasinya berdasarkan prinsip syariah. Hasil inilah yang melandasi didirikannya Islamic Development Bank (IDB).

\subsection{Profit-Loss Sharing: Solusi Islam terhadap Alternatif Pengganti Pelarangan Bunga}

Sebagai alternatif sistem bunga dalam ekonomi konvensional, ekonomi Islam menawarkan sistem bagi hasil (profit and loss sharing) ketika pemilik modal (surplus spending unit) bekerja sama dengan pengusaha (deficit spending unit) untuk melakukan kegiatan usaha. Apabila kegiatan usaha menghasilkan, keuntungan dibagi bersama dan apabila kegiatan usaha menderita kerugian, kerugian juga ditanggung bersama. Sistem bagi hasil ini dapat berbentuk mudharabah atau musyarakah dengan berbagai variasinya.

Dalam mudharabah terdapat kerja sama usaha antara dua pihak dimana pihak (shahibul mal) menyediakan seluruh modal, sedangkan pihak lainnya sebagai mudharib (pengelola). Keuntungan usaha secara mudharabah dibagi menurut kesepakatan yang dituangkan dalam kontrak, sedangkan apabila rugi ditanggung oleh pemilik modal selama kerugian itu bukan akibat kelalaian mudharib. Namun, seandainya kerugian itu diakibatkan karena kelalaian mudharib, maka mudharib juga harus bertanggung jawab atas kerugian tersebut (Antonio, 2001). Alternatif pengganti bunga yang lain adalah partisipasi modal (equity participation) melalui ekspektasi rate of return yang disebut sebagai musyarakah. Sektor riil merupakan sektor yang paling penting disorot dalam ekonomi Islam karena berkaitan langsung dengan peningkatan output dan akhirnya kesejahteraan masyarakat. Segala komponen dalam perekonomian diarahkan untuk mendorong sektor riil ini, baik dalam memotivasi pelaku bisnis maupun dalam hal pembiayaannya (Masyhuri, 2005). 
Ekspektasi return, berbeda dengan suku bunga yang selalu dijustifikasi oleh time value of money, namun justru dikaitkan dengan economic value of money. Dengan demikian, faktor yang menentukan nilai waktu adalah bagaimana seseorang memanfaatkan waktu itu. Semakin efektif dan efisien, maka akan semakin tinggi nilai waktunya. Dengan pemanfaatan waktu sebaik-baiknya untuk bekerja dan berusaha akan menghasilkan pendapatan yang dapat dinilai dengan uang. Hal ini bertentangan dengan time value of money, yang tidak secara proporsional mempertimbangkan probabilitas terjadinya deflasi, selain adanya inflasi. Karena pada realitanya, ketidakpastian (uncertainty) selalu terjadi, dan sangat menjadi tidak adil jika hanya menuntut adanya kepastian, seperti yang berlaku dalam ekonomi konvensional melalui konsep time value of money-nya. Oleh karena itu, pemodal dalam Islam tidak berhak meminta rate of return yang nilainya tetap dan tidak seorangpun berhak mendapatkan tambahan dari pokok modal yang ditanamkannya tanpa keikutsertaannya dalam menanggung resiko (Masyhuri, 2005).

Dengan demikian, menurut Ascarya (2007) kedua sistem profit and loss sharing ini, baik mudharabah dan musyarakahakan mampu menjamin adanya keadilan dan tidak adanya pihak yang tereksploitasi (terdzalimi). Melalui sistem bagi hasil ini juga akan terbangun pemerataan dan kebersamaan serta menciptakan suatu tatanan ekonomi yang lebih merata. Sedangkan dalam perekonomian konvensional, sistem riba, fiat money, commodity money, dan pembolehan spekulasi akan menyebabkan penciptaan uang (kartal dan giral) dan tersedotnya uang di sektor moneter untuk mencari keuntungan tanpa resiko. Akibatnya, uang atau investasi yang seharusnya tersalur ke sektor riil untuk tujuan produktif sebagian besar lari ke sektor moneter dan menghambat pertumbuhan bahkan menyusutkan sektor riil. Selanjutnya penciptaan uang tanpa adanya nilai tambah akan menimbulkan inflasi. Pada akhirnya, pertumbuhan ekonomi yang menjadi tujuan akan terhambat (lihat Gambar 2).

Gambar 2. Implikasi Bunga pada Perekonomian

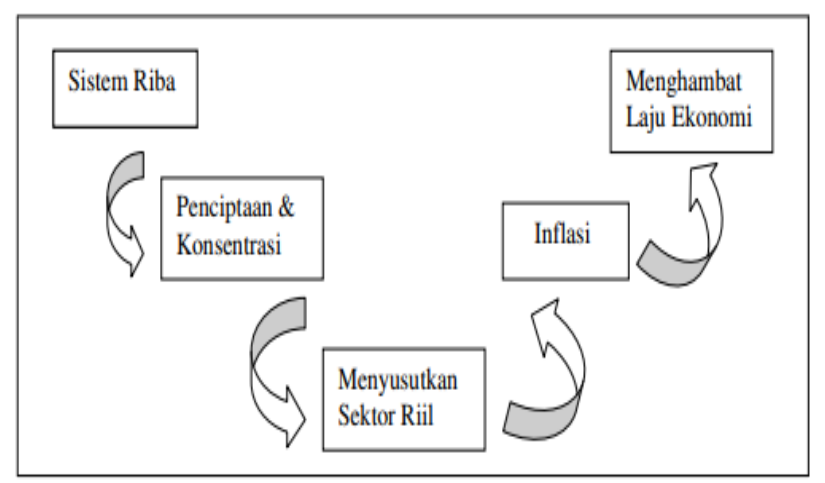

Sumber: (Ascarya, 2007: 27)

Dengan demikian, Islam mendorong praktik profit and loss sharing (sistem bagi hasil) dan

Tabel 2. Perbedaan antara Bunga dan Bagi Hasil

\begin{tabular}{ll}
\hline \multicolumn{1}{c}{ Bunga } & \multicolumn{1}{c}{ Bagi Hasil } \\
\hline $\begin{array}{l}\text { Penentuan bunga dibuat pada waktu akad dengan } \\
\text { asumsi usaha akan selalu menghasilkan } \\
\text { keuntungan. }\end{array}$ & $\begin{array}{l}\text { Penentuan besarnya rasio atau nisbah bagi hasil } \\
\text { disepakati pada waktu akad dengan berpedoman } \\
\text { pada kemungkinan untung rugi. }\end{array}$ \\
\hline $\begin{array}{l}\text { Besarnya presentase didasarkan pada jumlah } \\
\text { dana/modal yang dipinjamkan. }\end{array}$ & $\begin{array}{l}\text { Besarnya rasio bagi hasil didasarkan pada jumlah } \\
\text { keuntungan yang diperoleh. }\end{array}$ \\
\hline $\begin{array}{l}\text { Bunga dapat mengambang/variabel, dan besarnya } \\
\text { naik turun sesuai dengan naik turunnya bunga } \\
\text { patokan atau kondisi ekonomi. }\end{array}$ & $\begin{array}{l}\text { Rasio bagi hasil tetap tidak berubah selama akad } \\
\text { masih berlaku, kecuali diubah atas kesepakatan } \\
\text { bersama. }\end{array}$ \\
\hline $\begin{array}{l}\text { Pembayaran bunga tetap seperti yang dijanjikan } \\
\text { tanpa pertimbangan apakah usaha yang dijalankan } \\
\text { peminjam untung atau rugi. }\end{array}$ & $\begin{array}{l}\text { Bagi hasil bergantung pada keuntungan usaha yang } \\
\text { dijalankan. Bila usaha merugi, kerugian akan } \\
\text { ditanggung bersama. }\end{array}$ \\
\hline $\begin{array}{l}\text { Jumlah pembayaran bunga tidak meningkat } \\
\text { meskipun keuntungan naik berlipat ganda }\end{array}$ & $\begin{array}{l}\text { Jumlah pembagian laba meningkat sesuai dengan } \\
\text { peningkatan keuntungan. }\end{array}$ \\
\hline $\begin{array}{l}\text { Eksistensi bunga diragukan (kalau tidak dikecam) } \\
\text { oleh semua agama }\end{array}$ & \begin{tabular}{l} 
Tidak ada yang meragukan keabsahan bagi hasil. \\
\hline Sumber Antanio(2001:61)
\end{tabular} \\
\hline
\end{tabular}

Sumber: Antonio(2001:61) 
mengharamkan riba (bunga). Meskipun keduaduanya dapat memberikan keuntungan bagi pemilik modal, namun keduanya memiliki perbedaan yang sangat mendasar. Perbedaan itu dapat dijelaskan dalam Tabel 2.

Sementara itu, dengan sistem bagi hasil dan pelarangan riba dalam perekonomian Islam akan mendorong iklim investasi yang akan tersalur dengan lancar ke sektor riil untuk tujuan yang sepenuhnya produktif. Hal ini akan menjamin terdistribusinya kekayaan dan pendapatan serta menumbuhkan sektor riil. Dengan meningkatnya produktivitas dan kesempatan bekerja dan berusaha pada akhirnya pertumbuhan ekonomi akan terdorong dan pada akhirnya akan tercapai kesejahteraan masyarakat (lihat Gambar 3).

Gambar 3. Implikasi Bagi Hasil pada Perekonomian

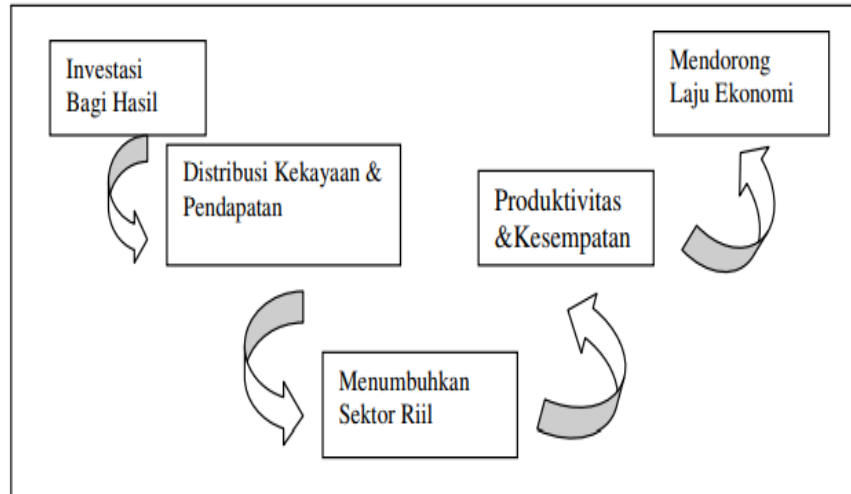

Sumber: Ascarya(2007).

Uraian dan gambaran di atas menunjukkan bahwa model profit and loss sharing merupakan model sistem keuangan Islam non-ribawi (tidak berbasis bunga), yang dapat menjadi solusi alternatif bagi sistem perbankan. Model ini dapat memberikan implikasi terhadap terciptanya aktivitas ekonomi yang adil, stabil dan sustainable menuju tercapainya kesejahteraan masyarakat.

\section{Kesimpulan}

Lahirnya sistem ekonomi Islam didasarkan pada pemikiran bahwa sebagai agama yang lengkap dan sempurna, Islam tidak hanya memberikan penganutnya aturan-aturan soal ketuhanan dan iman, namun juga menjawab persoalan yang dihadapi manusia termasuk ekonomi. Tujuan dari adanya Ekonomi Islam untuk mencapai sukses atau falah (kebahagiaan, kemenangan) manusia di dunia dan di akhirat. Riba adalah pengambilan tambahan, baik dalam transaksi jual beli maupun pinjam-meminjam secara batil atau bertentangan dengan prinsip muamalah dalam Islam.Konsep riba sebenarnya sudah lama dikenal dan banyak mengalami perkembangan dalam pemaknaan. Riba bukan hanya diperbincangkan oleh umat Islam saja, tapi berbagai kalangan non-Islam (Hindu, Budha, Yahudi, Yunani, Romawi dan Kristen) pun memandang riba sebagai permasalahan yang serius. Landasan hukum yang digunakan sebagai pedoman atas pelarangan riba bersumber pada Al-Quran, As-Sunnah dan Ijma. Ketiga sumber tersebut sepakat bahwa riba adalah haram, baik sedikit maupun banyak. Riba merupakan salah satu dari tujuh dosa besar yang harus dihindari.Sebagai alternatif sistem bunga dalam ekonomi konvensional, ekonomi Islam menawarkan sistem bagi hasil (profit and loss sharing) ketika pemilik modal (surplus spending unit) bekerja sama dengan pengusaha (deficit spending unit) untuk melakukan kegiatan usaha.

\section{Ucapan Terimakasih}

Penulis menyadari sepenuhnya bahwa banyak pihak yang telah membantu dalam penulisan jurnal ini. Segala bentuk bimbingan, bantuan, dukungan, dan doa merupakan nikmat yang akan selalu Penulis syukuri. Oleh karena itu penulis mengucapkan terima kasih sebesarbesarnya kepada; 1) Kedua orang tua kami tercinta yang telah melahirkan, membesarkan, dan mendidik serta selalu memberikan dukungan doa yang terbaik kepada penulis. 2) Dr. Sri Herianingrum, S.E., M.Si. selaku Ketua Program Studi Magister Sains Ekonomi Islam, Sekolah Pascasarjana,Universitas Airlangga. 3) Seluruh dosen dan staf pengajar Magister Sains Ekonomi Islam, Sekolah Pascasarjana, Universitas Airlangga yang telah membantu dan memberikan ilmunya kepada penulis. 4) Sahabat seperjuangan, khususnya Dinda, Dipta, dan Faishol, terima 
kasih atas sharing ilmu yang bermanfaat kepada penulis, semoga sukses selalu.

\section{Daftar Pustaka}

Antonio, M. S. (2001). Bank Syariah Dari Teori Ke Praktik. Jakarta: Gema Insani Press.

Arif, M. N. R. Al. (n.d.). Modul 1 Filosofi Dasar Ekonomi Islam. Retrieved from http://repository.ut.ac.id/4013/1/ESPA4528M1.pdf

Arif, M. N. R. Al. (2015). Pengantar Ekonomi Syariah. Bandung: Pustaka Setia.

Ascarya. (2007). Akad dan Produk Bank Syariah. Jakarta: Raja Grafindo Persada.

Boediono. (2011). Ekonomi Mikro. Yogyakarta: BPFE.

Chamid, N. (2013). Tantangan Sistem Keuangan Islam Sebagai Alternatif Sistem Keuangan Global. Jurnal Al-'Adl, 6(2), 110-127.

Hidayanto, M. F. (2008). Praktek Riba dan Kesenjangan Sosial. La Riba, Jurnal Ekonomi Islam, 2(2), 239-261.

Iljas, A. (2007). Sistem Ekonomi Islam (Syariah) dan Permasalahan Bunga Bank. Tarjih, 9, 37-68.

Iqbal, Z., \& Mirakhor, A. (2011). An Introduction to Islamic Finance (second edi). Singapore: John and Wiley (Asia) Pte. Ltd.
Islahi, A. A. (1988). Economic Concepts of Ibn Taimiyah. London: The Islamic Foundation.

Karim, A. (2007). Bank Islam: Analisis Fiqih dan Keuangan. Jakarta: Raja Grafindo Persada.

Khan, M. A. (1994). An Introduction to Islamic Economic. Islambad, Pakistan: International institute of Islamic Thought and Institute of Policy Studes (IIIT).

Mannan, M. A. (1997). Islamic Economic, Theory and Practice. Yogyakarta: Dana Bhakti Wakaf.

Masyhuri. (2005). Teori Ekonomi dalam Islam. Yogyakarta: Kreasi Wacana.

Mujahidin, A. (2013). Ekonomi Islam Sejarah, Konsep, Instrumen Negara dan Pasar. Jakarta: Raja Grafindo Persada.

Rahmawaty, A. (2013). Riba dalam Perspektif Keuangan Islam. Jurnal Hukum Islam, 14(2).

Rivai, V., Veitzhal, A. P., \& Idroes, F. N. (2007). Bank and Financial Institution Management Conventional and Sharia System. Jakarta: Raja Grafindo Persada.

Samuelson, P. A., \& Nordhaus, W. D. (2001). Microeconomics. New York: McGraw-Hill Irwin. 